\title{
Political Theory of Societal Association: Case of the Failed State of Syria-Part 2
}

\author{
Frederick Betz \\ Institute for Policy Models, Enumclaw, WA. USA \\ Email: fbetz@venture2reality.com
}

How to cite this paper: Betz, F. (2020). Political Theory of Societal Association: Case of the Failed State of Syria-Part 2. Open Journal of Social Sciences, 8, 504-529. https://doi.org/10.4236/jss.2020.86038

Received: March 1, 2020

Accepted: June 27, 2020

Published: June 30, 2020

Copyright $\odot 2020$ by author(s) and Scientific Research Publishing Inc. This work is licensed under the Creative Commons Attribution International License (CC BY 4.0).

http://creativecommons.org/licenses/by/4.0/

\begin{abstract}
This is the second paper (of four) analyzing the failure of the Syrian state. Four papers have been required because of the complicated sequence of events in the history of Syria: 1) from territory from the Ottoman Empire to European colonial states, 2) to independent states, 3) to a near collapse under a terrorist caliphate, and 4) to refugee impacts on its former colonial occupiers. In this historical sequence, we are testing the validity of the modern theory of political association. In the previous paper of Part 1, we constructed this formal theory as a 3-D taxonomy of political association, which we used to analyze why the state of Syria failed in a vicious civil war (Betz, 2019). The history of modern Syria began at the end of the Ottoman Empire, from which the modern Middle East states were carved. Because of the complex details of the government of Syria after independence, we here review these events as a second paper, Part 2. This paper continues using the methodology of grounding social science theory upon historical studies.
\end{abstract}

\section{Keywords}

Civilization, Failed States, Political Theory, Middle East, Colonialism

\section{Introduction}

In an earlier paper, we analyzed the emergence of the states of the Middle East as colonies of France and Europe at the end of World War I (Betz, 2019). In these colonial states, the new Middle Eastern intellectuals opposed colonial occupation in all the states created by the war-time Skykes-Picot agreement. Next at the end of the Second World War, insurection and international politics forced the British and French to finally yield their North African colonies. Figure 1 lists the dates after the Second World War, when France and Britain were forced to yield their colonial empires in North Africa. Syria gained independence in 1946. 


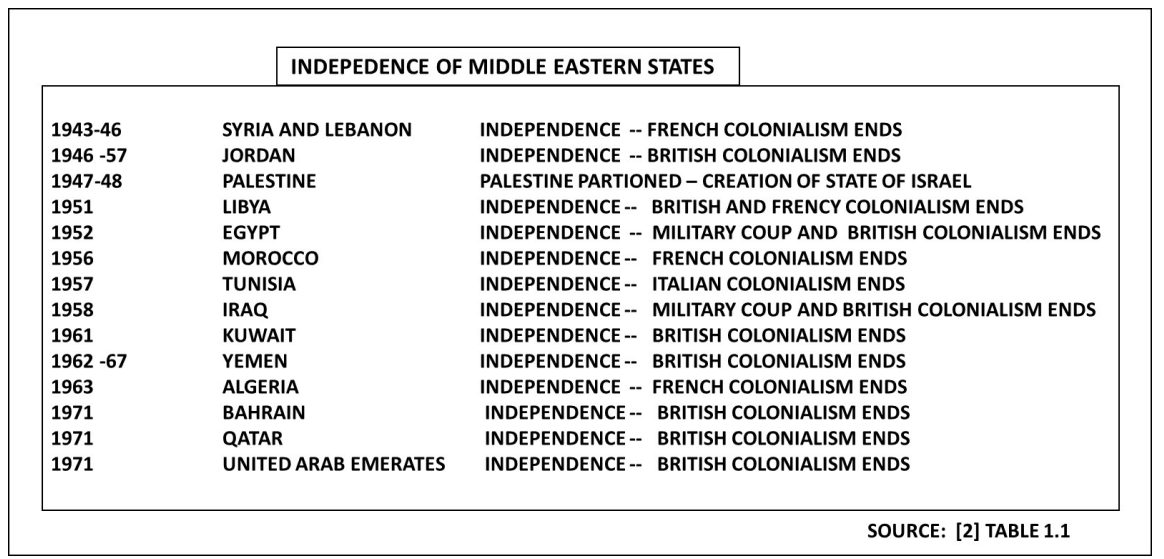

Figure 1. Independence of middle eastern states. Source: (Milton-Edwards, 2018).

\section{Ideology and Reality in the Independent Syria}

From the end of the Ottoman Empire and up to independence of the states of the Middle East (which we earlier analyzed in the paper of Part 1) a theory of political association explained why state failures occur (Betz, 2019). Shown again in Figure 2, the theory of the state of political association was constructed from three basic political science dichotomies of genetic \& reciprocal altruism, centralized \& decentralized power, idealism \& realism of power.

In the $3 D$ theory of political association, along the Realistic dimension of political association in the post-Ottoman Middle East, European Colonialism divided territories into "States", under British or French control. Yet the people in the states self-associated Realistically, not as citizens of States, but as members of Tribes (dominantly as Sunni, Shia, or Kurds, in Kinship or Religious association). None of these ex-colonial states achieved a Realistic association as a "Nation" - because participants did not perceive that they were given a reciprocal social contract by their colonial masters. (See paper (Betz, 2019) for discussion of the difference between the concepts of nation and state.)

Along the Idealistic dimension of political association in the colonial Middle East, an Ideology of Independence spread, organizing either under a mythic Arab Nationalism or a political pan-Islamism. The ideal was to achieve an Arab nationalism - in which Independence would actually be pursued, state by state, after the Second World War.

Historically, there was an Arab Empire ended by the Mongol invasions; but in the modern Middle East, this was viewed as a "civilization" of mythic proportions to justify local indignation at recent European colonialism. It was during the era of European colonialism of the Middle East, that the loyality in the Middle East intellecturals had focused upon this "Arab nationalism" and "pan-Islamism". Arab nationalism was an ideal, which had arisen as a response 1) to the collapse of the Ottoman Empire and 2) to the imposition of European colonialism. In the Ottoman Empire, all schools were taught in Turkish. All post Ottoman Middle Easern states were under European collonial occuation. But under occupation, the Arabic language was revived in the schools and in the press (except in Turkey, 


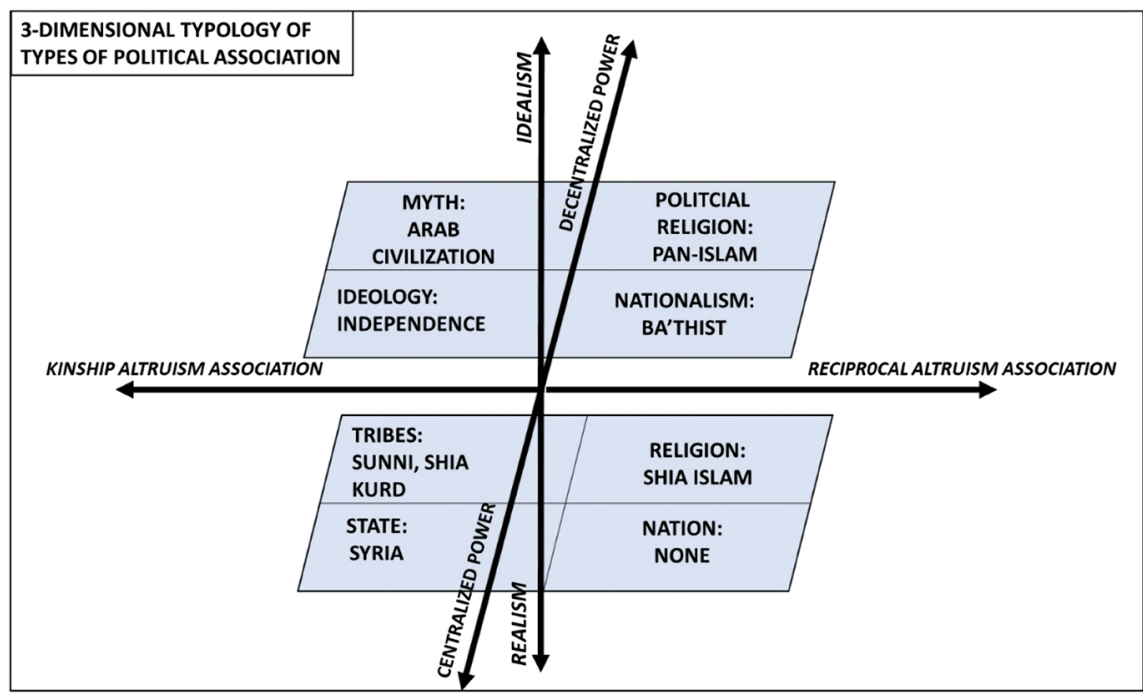

Figure 2. 3-Dimensional theoretical typology of political association. Source: (Bell, 2014).

where modern Turkish was instituted). Arab intellectuals began spreading their ideas of an Arab nation.

Also a pan-Islamic movement, an Arab politization of Islam, rose to challenge the collonial occupation. Beverly Milton-Edwards wrote: "The founder of the pan-Islamic trend was an Iranian-born Muslim Thinker Jama ad-din al-Afgahani (1838-97) who called upon fellow muslims ... to reassess the role of Islam in their lives ... (Later thinkers added) ... to reacquaint Islam with the immense political, social, and economic changes taking place around them, as a direct result of the colonial experience." (Milton-Edwards, 2018)

Between the two World Wars of the twentieth century, the colonial repression of Middle Eastern elites stimulated the desire for independence, but without commitments to democracy. Syria and others created authoritarian regimes, appealing to a justification of governance based upon Arab nationalism and/or Pan-Islamism. Beverly Milton-Edwards wrote: "(In the Middle East) ... patriotic nationalism is inextricably linked to more than a decade of revolution of independence, which befell the region after the Second World War. Revolutions (a coup d'état or independence) were achieved in countries like Egypt, Lebanon Syria, Iraq, Libya, Tunisia, Morocco Transjordan, Algeria and Yemen. By the early 1970s, a new era had been proclaimed in the region... (Then) other factors (to Arab nationalism and Pan-Islamism) needed to be addressed-including the swing within the Third World as a whole to revolutionary regimes ... Also the impact of global capitalism on 'emerging oil economies' in the Arabian Gulf needed to be factored into this 'nationalism' issue ... And another factor was important. This is the 'Palestine issue'." (Milton-Edwards, 2018)

After the end of the First World War and the Ottoman Empire, colonial states in the Middle East were carved out-in such forms that set one clan or tribe against another. Between the First and Second World Wars, British and French colonial powers over the carved-out states of the Middle East suppressed their 
indigenous elites - who might have helped evolved Middle Eastern "states" into modern "nations". The exception was Turkey-which Mustapha Kemal had saved from colonial subjugation and which did evolve into a nation, and not merely a state. After the end of the Second World War, the British government, in April 1946, forced the former Vichy French government officials in Syria to withdraw their French troops from Syria and Lebanon.

\section{Divisions within Independent Syria}

Now we will analyze how the independent Syria remained a state and did not evolve into a nation. The territory of Syria contained many religious and tribal divisions. Beverly Milton-Edwards wrote: "Syria is not an ethnic nor sectarian homogeneous state. Since the creation of the new state of Syria in 1920, initially under the French mandate, a mosaic of minorities have made up its population. The minorities include Alawites, Kurds, Druze, Christians, Turks, Circassian, Armenians, Assyrians, Jews and Maronites. While some 90\% of the population is Arab, minority status in term of religious confession and sect is also important. The largest religious group consists of Sunni Muslims who live in the urban areas of Damascus, Aleppo and Homs and Hama. The Alawite Muslims, a Shi'a sect from the coastal areas of Syria, constitute $15 \%$ of the population and ... dominated the Ba'athist state." (Milton-Edwards, 2018)

Figure 3 shows roughly the major ethnic (tribal and religious) divisions existing in Syria.

In Syria, the ideology of Arab nationalism led to the establishment of the Ba'th political party. It was founded in the 1940 by two Syrian intellectuals, Michel

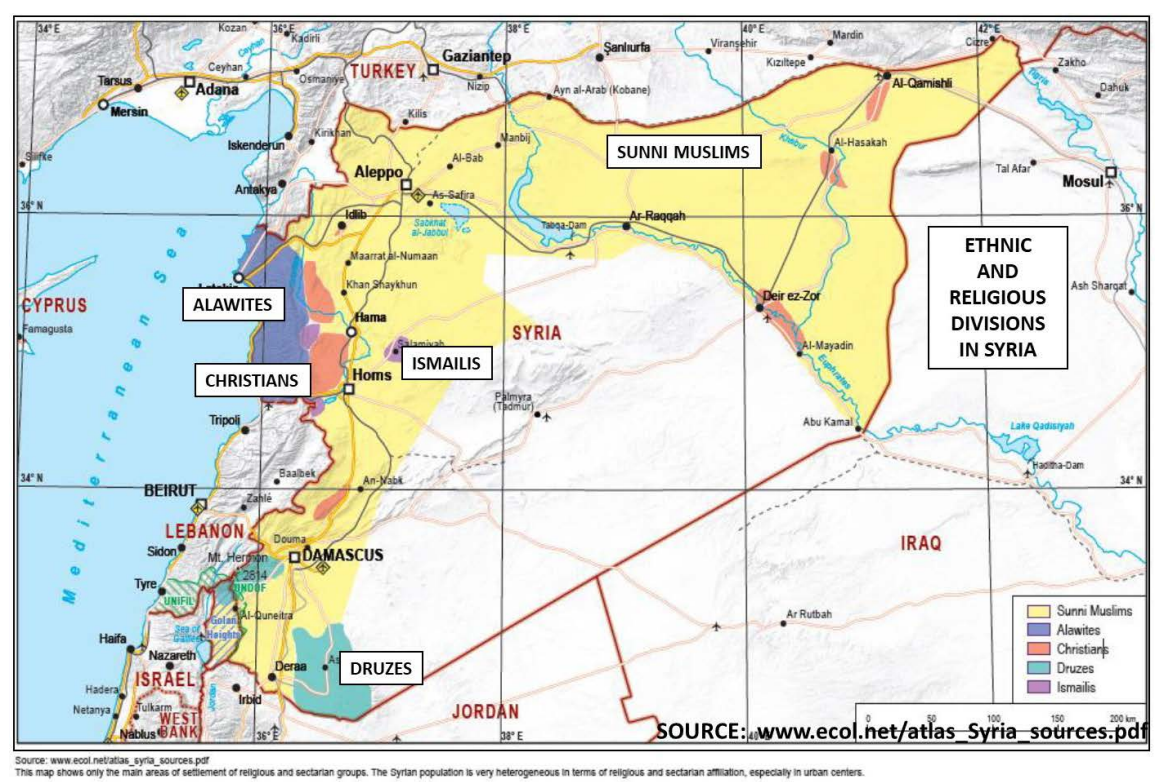

Figure 3. Ethnic divisions in Syria before the civil war beginning in 2010. Source: Columbia University Gulf/2000 Project, and http://www.washingtonpost.com/blogs/worldviews/wp/2013/08/27/the-one-map-that-sh ows-why-syria-is-so-complicated. 
Aflaq and Salah ad-in al-Bitar and held its first congress in Damascus in 1947: establishing Ba'th branches in Syria, Iraq, Jordan and Lebanon. Its ideology called for pan-Arab unity, with policies of socialism and liberation. Beverly Milton-Edwards wrote: "From the 1970s to the end of the 1980s, Ba'thism played a pivotal ideological role in the states of Syria and Iraq. Ba'thism subsequently became associated with one-party rule, a lack of democracy, militarized society and dictatorship." (Milton-Edwards, 2018)

The Idealism of Ba'thism began with Arab unity, socialism, and liberation; but the political Reality (Real Politic) morphed into one-party rule, dictatorship, and a militarized society.

The territory of Syria encompassed several ancient kingdoms, with the cities of Damascus and Aleppo as some of the oldest cities in the world. In ancient Arab times, Damascus was the capital of the Umayyad Caliphate. This was the ancient history which, in the 1900s, Arab intellectuals looked backwards -- in order to base their pride against the indignities of colonialism. At the end of the war in 1946, Britain was in military control of Syria; and (since Vichy had been a puppet ally of Britain's enemy of Germany) Britain then liberated Syria from control of the French Vichy government. The state of Syria was independent.

Still independent Syria was a "state" and not a "nation"— not a nation with loyalty of universal citizens based upon a Rousseau kind of social contract (Betz, 2019). Instead, there were rival religious groups and clans vying for power. The minority group of Alawites won out in the struggle through military coups (in which the Ba'athist party and military took control of the government). Beverly Milton-Edwards wrote: "In considering the formation and structure of the modern Ba'athist state of Syria and the role of the Alawites within this, the crucial point is the rise of Alawites in the Syrian armed forces and the Ba'th Party... A power struggle within the officer corps of the Syrian army took place between the Sunni and other minority-based officers... There was first a purge of the Sunni officers. Finally in an internal Alawite power struggle, Hafez al-Assad defeated his co-religionist and fellow officer. Eventually President Assad had his successor son Bashar promoted, along with fellow Alawites in the army, the Ba'th party and state institutions... And over decades of rule, the al-Assads presided over the repression of the majority Sunni population... Their failure to provide a plural and democratic basis for politics and representation in minority states like Syria, led to internal crisis and communal conflict." (Milton-Edwards, 2018)

\section{Time-Line of Independent Syria 1946-1963}

Societal dynamics provides a cross-disciplinary analytical framework for depicting the history of a society as alternating models of stability, altered by historical events (change events) which change societal structures (Betz, 2011). Figure 4 summarizes the key change events on a societal-dynamic timeline for the state of independent Syria from 1946 to 1973. 


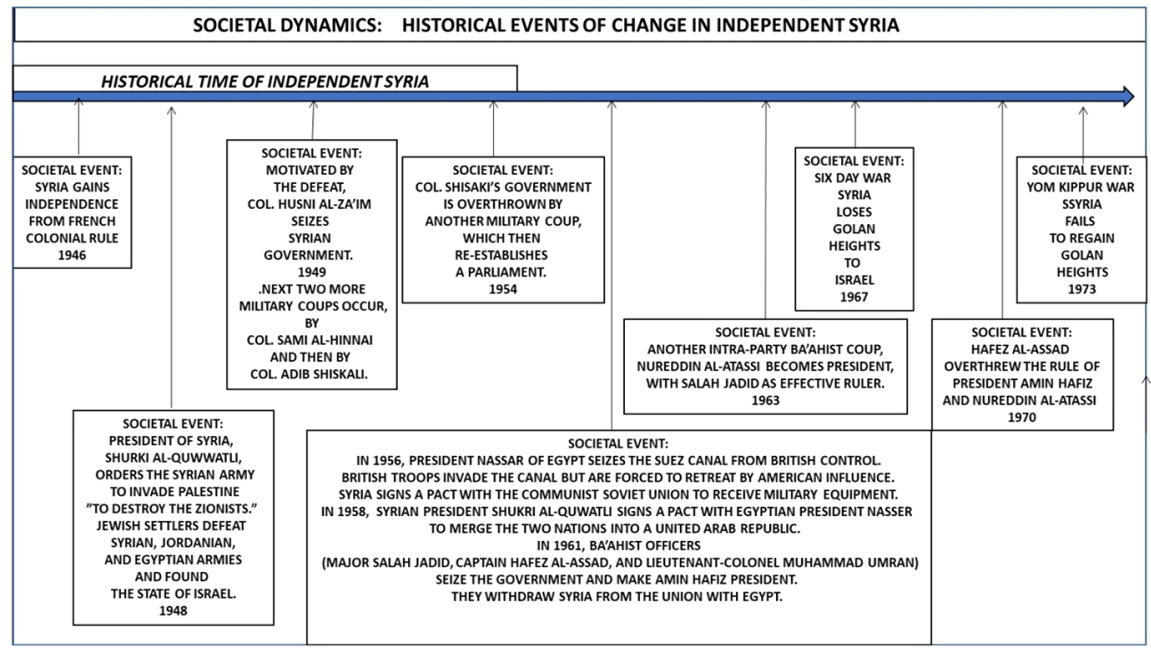

Figure 4. Timeline of historical change events in the government of independent Syria.

1946. Independence from French colonial control.

1948. President of Syria, Shurki al-Quwwatli, orders the Syrian army to invade Palestine, along with Jordanian and Egyptian armies. They attack Jewish settlements: "to destroy the Zionists". The Jewish settlers defeat the Syrian, Jordanian, and Egptian armies and found the state of Israel.

March 1949. Motivated by the defeat, a military coup d'état by Col. Husni al-Za'im seizes the Syrian government. Next two more military coups occur, by Col. Sami al-Hinnai and then by Col. Adib Shiskali. (In Egypt, a military coup by Nasser seizes the Egyptian government.)

1954. Col. Shisaki's government is overthrown by another military coup, which then re-establishes a parliament.

1956. President Nassar of Egypt seizes the Suez Canal from British control. British troops invade the Canal but are forced to retreat by American influence. Syria signs a pact with the communist Soviet Union to receive military equipment.

1958. Syrian President Shukri al-Quwatli signs a pact with Egyptian President Nasser to merge the two nations into a United Arab Republic.

1961. Ba'ahist officers (Major Salah Jadid, Captain Hafez al-Assad, and Lieutenant-Colonel Muhammad Umran) seize the government and make Amin Hafiz president. They withdraw Syria from the union with Egypt.

1963. Another intra-party Ba'ahist coup, arrests President Amin Hafiz; and Nureddin al-Atassi becomes president, but with Salah Jadid as effective ruler.

\section{3-1967. Salah Jadid, Ba'ahist, and Syrian Government}

In the 1963 coup, the officer corps of the Syrian Army had emerged as the dominant group in the Ba'ahist Party and Syrian Government. Raymond Hinnebush wrote: In the wake of its 1963 coup, the Ba'ath Party took power in a state, fragmented on identity lines and geographically truncated by the dismemberment of historic Syria by the Western powers. This state was an artificial cre- 
ation having to compete for the loyalty of its citizens... While Arabism, in bridging communal cleavages between the Sunni Arab majority and the mosaic of Arab minorities, was the main basis of cohesion, it also entangled the country in the politics of pan-Arabism and the conflict over Palestine and against eastern imperialism. The country was also divided on sharp class lines between the ruling landed and commercial oligarchy, a rising radical middle class (which came to dominate the army) and an aggrieved peasantry, a conflict that ultimately destabilized political life. The Ba'ath coup brought to power a new elite whose worldview was shaped by their rural backgrounds and involvement in the social and nationalist struggles of the 1950s." (Hinnebusch, 2012)

The Syrian Government after 1963 was dominated by the Alawites. Raymond Hinnebush wrote: "Officers from the minority Alawi sect emerged as a dominant clique owing to their disproportionate recruitment into the army and party before 1963. The regime managed, however, to break out of its isolation through a 'revolution from above' that broke the economic hold of the oligarchy, won the support of peasants with land reform, and created through nationalizations a public sector employing major segments of the middle and working classes. Investment in public health and education gave momentum to literacy and life expectancy increases that continued into the 1990s. Indicative of the regime's rural base, rural electrification rose from 2 per cent in 1963 to 95 per cent in 1992. In parallel, the regime sought to legitimize itself by adopting a stance of militant Arab nationalism ...” (Hinnebusch, 2012)

\section{7, Six Day War}

In June 1967 , between the $5^{\text {th }}$ and $10^{\text {th }}$, a Six-Day War was fought by Israel against Egypt, Jordan and Syria. Nasser distrusted Israel, especially after Israel's invasion of the Sinai in 1953 to support the British seizure of Nasser's nationalization of the Suez Canal. In May of 1976 (and after having been armed by the Soviet Union with weapons of planes, missiles, and tanks), Egyptian President Nasser announced a naval blockade to close the straits of Tiran to Israeli ships. The Israeli government regarded the blockade as act of war and in June launched an air raid on Egypt's air force and a tank invasion of Egypt's Sinai Peninsula. The Egyptian's defended their airfields with Russian surface-to-air missiles, destroying one-third of Israel fighter planes. But the other two-thirds of Israel's fighters got through and destroyed the Egyptian air planes on the ground. Israeli tanks with air cover rapidly occupied the Sinai to the Suez Canal, separating Sinai from the rest of Egypt. Jordan's army began attacks on Israel, but Israel forces defeated the Jordanian army and occupied the West Bank. Syria's forces were also defeated, with Israel occupying the Golan Heights, just outside Damascus. About 300,000 Palestinians fled the West Bank into Jordan and later into Lebanon. Syria had 75,000 troops, which were unable to stop Israel advances onto the Golan Heights. For the next four decades, Israel continued to occupy the West Bank and the Golan Heights.

Raymond Hinnebush wrote: Arab nationalism, however, led to Syria's defeat by Israel in the 1967 war and loss of the Golan Heights, shattering its nationalist 
legitimacy. This precipitated the rise in 1970 of a realist faction of the regime under Hafiz al-Assad, who reshaped the state for a protracted struggle with Israel over the occupied territories. Assad transformed an unstable regime into a robust one through a "neo-patrimonial" strategy that concentrated power in a "presidential monarchy" buttressed by his faction of Alawi lieutenants commanding the army and security forces. This patrimonial core was linked to society through bureaucratic and party-corporatist institutions that cut across sectarian and urban-rural divides, incorporated a constituency that spanned the middle class and the peasantry, and represented the interests of a sizeable regime coalition. The struggle with Israel, especially in the 1973 war, endowed the regime with a measure of nationalist legitimacy." (Hinnebusch, 2012)

\section{3, Yom Kippur War}

In 1973, from October 6 to 25, the Egypt and Syria launched attacks upon the Sinai and Golan Heights to seize back territory occupied by Israel in 1967. Anwar Sadat had succeeded Gamal Abdel Nasser as President of Egypt in 1971, after Nasser's death in 1970. Sadat had been a military colleague of Nasser in the Egyptian army (in the Arab-Israel war of 1946 and in the Six Days War of 1967). Sadat resolved to gain control of the Suez Canal by launching a raid into the Sinai, to repel Israeli occupation of the east bank of the Canal. The Syrian Army attacked the Israeli' occupied Golan Heights, and Jordan attacked the Israeli occupied West Bank. The attacks were launched on Yom Kippur, the holiest day in Judaism and caught the Israeli government and military by surprise. Sadat wished to inflict a limited defeat on Israel to force it to negotiate returning the Sinai. Hafez al-Assad wanted to seize back the Golan Heights. King Hussein of Jordan refused to participate in the attacks. Egyptian forces successfully crossed the Suez Canal and advanced into the Sinai. But in three days, Israel had mobilized its forces and halted the Egyptian advance. The Syrians made an advance into the Golan Heights, but the Israeli army resisted and forced the Syrian army back to cease-fire lines. Israel forces the launched a counter-offensive deep into Syria, shelling the outskirts of Damascus. In the Sinai, Israeli forces launched a counterattack pushing Egyptian forces back across the Canal and then advanced toward Cairo. But they then stopped their advance at the strong urging of Russia and the U.S.

\section{Hafez Al-Assad's Alawite Government of Syria}

Because of the Syrian war failure in 1967, Hafez al-Assad in 1970 overthrew the rule of President Amin Hafiz and Nureddin al-Atassi. Hafez al-Assad then established a stable regime in Syria. But it was not one which was militarily strong, losing a second war against Israel and not regaining the Golan Heights. The Syrian Army was organized with Alawite officers and had been focused upon suppressing a majority population of Sunni Muslims. Raymond Hinnebush wrote: "Hafez's regime, though very durable, had built-in vulnerabilities that had to be constantly addressed. The domination of the political elite by Alawi officers of 
rural origin provoked resentment among the majority Sunni community and especially the urban merchant-clerical complex represented by the Muslim Brotherhood, which led several urban rebellions, including the insurrection that rocked the northern cities in the early 1980s." (Hinnebusch, 2012)

The way Hafez al-Assad created stability was to have security organizations, controlling political opposition and offering economic opportunities to political supporters. Annette Buchs wrote: "The Syrian regime, under Hafiz al-Assad had a relatively high ability to employ punitive inducements in order to gain obedience. The regime had, first, successfully organized its 'instruments' of repression in a voluminous and all-pervading security apparatus. Secondly, it had secured its control over that apparatus through the employment of dependency-creating material inducements and the employment of 'checks' that balanced, curtailed, and controled the various forces." (Büchs, 2009)

Coercion was the principle means of political control by al-Assad's Bah'ist government of the Syrian population. Annette Büchs wrote: "The security apparatus was of considerable size, comprising police, military forces, and mukhabarat (security services). The mukhabarat consisted of several legally unchecked services conducting surveillance in an open rather than secretive fashion through a dense and ubiquitous net and pervading 'all parts of society, including the bureaucracy, the party and the army,' thereby creating a constant ambience of fear. The President repeatedly proved that he could strip any military and security strongman of his position." (Büchs, 2009)

Thus al-Asaad's regime ruled through both coercion and material incentives. Annette Büchs wrote: "Material incentives included employment, as the security apparatus employed around half of all state employees. It provided career chances and certain privileges for its members. These included, for example, tax exemptions; higher wages than in other areas of the public sector; more entrepreneurial freedom (in the military-economic sector) than in the rest of the public sector; possible political influence and prestige (as many key political positions were held by officials of the security apparatus); and the opportunity for personal enrichment through illegal activities such as corruption, patronage, smuggling, etc. This web of material privileges and dependency extended even to civilians, as knowing a member of the Mukhabarat helped one to attain privileges and because there was a growing connection between the military-economic sector and the commercial bourgeoisie (Büchs, 2009).

Hassan Al-Asaad had established his regime's power over three periods. The first period in 1963-1970, focused upon establishing loyalty in peasants and workers. His Ba'ath Party initially instituted a radical land reform, expropriating land from the older group of large land owners and redistributing land to peasants. The Alawite group initially had largely been peasants. In addition, the regime expanded government employment in the security sector, building a middle class of wage earners. Annette Büchs wrote: “The Ba'th thereby radically inverted the severe urban-rural conflict that had arisen in the 1950s and thus enabled the regime to create new power through this re-stratification. It created 
a constituency, its rural base, based not only on material inducements but also on a certain degree of legitimacy. Thus, as material inducements receded later on, this constituency then proved to be a rather stable pillar of the regime." (Büchs, 2009)

Hassan al-Assad continued to build his regime's power during a second period from 1970 to the mid-1980s, based upon Syrian oil production and a rapid raise in oil prices after the Six Days Israel-Arab war. Annette Buchs wrote: "The second period, from 1970 to the mid-1980s, saw a movement away from the radical exclusion of the old oligarchy of landlords and capitalists, and instead saw the incorporation of a relatively broad and diverse spectrum of societal groups. This generous incorporation, and thus distribution of economic rewards, was made possible by the rather big flow of foreign, especially Arab, aid after 1973, as well as by the dramatic rise in oil prices, both of which can be seen as making Syria an 'indirect rentier-state.' ... This most notably created a new commercial bourgeoisie 'fed' by the state's exaggerated economic role and thus dependent on its control over resources and the market. The main ally in the new coalition following Assad's assumption of power, however, was the 'wage-earning middle classes,' together with, though to a lesser extent, the urban working classes. Both groups, but especially the first, were dependent on the expansion of the state's apparatus. The inducements of employment, relatively good wages, and certain services and benefits-such as free medical care, the provision of kindergartens, etc.-won these groups into the coalition and tied them at the same time to the state by creating their dependency on the state's employment and wage policies." (Büchs, 2009)

Finally, there was a third period in al-Assad's continuing hold on power. There were severe economic crises in the 1980s, encouraging the regime to move away from economic liberalization and back toward state control of the economy. This weakened al-Assad's hold on Syrians, other than Alawites. And during this time, the Sunni-based group of the Muslim Brotherhood increased terror attacks on the al-Assad regime.

But the Shi'ite Alawite control of the government and economy had not gained loyalty of the majority of Syrians, the Sunni Muslims. A jihadist group of the Sunni Muslims, which called themselves the "Muslim Brotherhood" began an armed insurrection against the Alawites in the period from 1972 to 1982. In 1979, an armed group entered the Aleppo Artillery School and massacred 32 Alawite cadets. The Muslim Brotherhood continued attacks against the Ba'ath Party, police posts and barracks and against factories, killing over 300 people.

In 1980, strikes and protests occurred in several Syrian cities; and in June, an assassination attempt was made upon the President al-Assad. The Army responded by massacring Sunni inmates in a prison. In 1982, the Army entered Hama and massacred thousands of Sunni citizens. Robert D. Kaplan wrote: "In February of 1982, the Sunni Arab Muslim Brotherhood took control of Hama and murdered its Alawite-appointed officials. Sunni renegades had earlier massacred Alawite soldiers in Aleppo... Assad reacted by sending 12,000 Alawite 
soldiers into Hama. They massacred as many as 30,000 Sunni Arab civilians and leveled much of the town. In 1982, Hama was proof that beneath the carapace of Assad's stable rule lay a seething region that was no closer to nationhood than it had been after the Turks left, or after the French left." (Kaplan, 1993)

Raymond Hinnebush wrote: "The brutal suppression of that revolt was successful because the army, Damascus and the rural constituency of the Ba'ath remained loyal. Especially after this episode, multiple intelligence agencies and praetorian guard units proliferated to protect the regime; these had to be kept loyal through tolerance of their corrupt practices and immunity from the law, practices that became a drain on the public sector and an obstacle to revival of the private sector. The public sector failed as an engine of capital accumulation because it was used to provide populist benefits such as jobs and subsidized food and patronage for the regime constituency. Alienated private capital fled the country or refrained from investment, except in tertiary sectors that yielded quick profits. The conflict with Israel also diverted resources from economic development into an oversized military, kept relations with the West fraught and put off investors. This national security state, overdeveloped relative to its economic base, generated a permanent fiscal deficit that could only be sustained by external 'rent'. However, Hafiz al-Assad was able to use a nationalist foreign policy and Syria's status as a front-line state bordering Israel to get aid from the Arab Gulf states and cheap arms from the Soviet Union." (Hinnebusch, 2012)

\section{Structural-Functional Models of a Society}

The earlier model we had constructed for the theory of political association is a thematic model of explanation of the themes (or ideas) impacting the perceptions of member associating with each other to form sociological groups (Betz, 2019). But this thematic model does not indicate how the ideas are implemented into a society-how the ideas guide general patterns of behavior. In a society, general patterns of shared (common) behavior occur in the institutions of the society. Institutions provide guidelines and references for individual behavior within the institutions. The depiction of institutionalized general patterns of behavior has been called a "societal structure" by sociologists. And the benefits to society of institutionalized behavior has been called "functionalism" by sociologists.

In the history of sociology, there was in the U.S. schools of sociology, a structure-functional school, which was popularized by Talcott Parsons. He used the term "structural functionalist" in his social theory of action. By the term "social structure" Parsons indicated the patterns in the social arrangements of life, and by the term "functionalism" Parsons indicated the relevance of the social patterns (structure) to the participants in the society. Parsons also formulated social theory in what he called "action theory" (Parsons, 1951).

The organizational structure of a society provides the functions necessary for the institutionalized patterns of behavior in a society to benefit participants in a 
society. Ideas shared in social groups become implemented as general patterns of behavior within a group, by the "institutionalization" of the ideas (as the basis of social-political order).

To construct a general structural-functional model of a modern society, one can use basic ideas about social interactions formulated by Max Weber. Weber had proposed that, in a modern society, all social interactions occur with two sets of expectations (Weber, 1947). Participants in a society interact with the expectation on either party as being either one of "identity" or of "utility". At the same time, the participants interact also with the expectation of the interaction as being based upon "reciprocity" or "authority".

By the dichotomy of "utility or identity", Weber meant that in any societal interaction, each party to the interaction will anticipate either:

1) Utility in a relationship - as a useful value for a participant in the interaction (such as buying or selling goods):

2) Identity in the relationship-as an identification of one party with the other party as belonging to some same group and sharing the values of the group (such as belonging to the same family or same political party).

By the dichotomy of "reciprocity or authority", Weber meant that in any societal interaction, each party will also anticipate as a basis for the interaction either:

1) Reciprocity in the relationship - as a mutual and equal advantage for each party in the relationship,

2) Authority in a the relationship - as one of the parties in the relationship for making decisions about the relationship (such as one being a judge and the other a plaintiff or one being a mayor of a city and the other a citizen.

In a previous book, the author had used both Weberian dichotomies to construct a taxonomic model of society (Betz, 2011). As shown in Figure 5, a taxonomy of societal interactions can be constructed in matrix form-with utility-identity

\begin{tabular}{|c|c|c|}
\hline \multicolumn{3}{|c|}{$\frac{\text { TAXONOMY OF FUNCTIONAL SYSTEMS }}{\text { IN A MODERN SOCIETY }}$} \\
\hline \multirow[b]{2}{*}{ RECIPROCITY } & UTILITY & IDENTITY \\
\hline & $\begin{array}{c}\text { ECONOMIC } \\
\text { INFRASTRUCTURES } \\
\text { \& PROCESSES } \\
\text { (ECONOMIC SYSTEM) }\end{array}$ & $\begin{array}{c}\text { CULTURAL } \\
\text { INFRASTRUCTURES } \\
\text { \& PROCESSES } \\
\text { (CULTURAL SYSTEM) }\end{array}$ \\
\hline AUTHORITY & $\begin{array}{l}\text { TECHNOLOGICAL } \\
\text { INFRASTRUCTURES } \\
\text { \& PROCESSES } \\
\text { (SCIENCE \& } \\
\text { TECHNOLOGY } \\
\text { SYSTEM) }\end{array}$ & $\begin{array}{l}\text { POLITICAL } \\
\text { INFRASTRUCTURES } \\
\text { \& PROCESSES } \\
\text { (POLITICAL } \\
\text { SYSTEM) }\end{array}$ \\
\hline
\end{tabular}

Figure 5. Taxonomy of the functional systems in a modern society. 
sitting across the top of the matrix and reciprocity-authority down the side of the matrix.

Social interactions which anticipate benefits of both utility and identity are characteristic of economic interactions. Two participants each expect from their interaction both usefulness (utility) and that utility should be fair (reciprocal) in mutual benefit. For example in an economic system, two participants in a market, as buyer and seller, expect 1) both to benefit from the sale (product for the buyer and price to the seller) and 2) that the sale should be fair (a competitive price for a quality product).

Next one can call the kind of social interactions in which participants anticipate benefits of both utility and identity as a kind of cultural interaction. Therein two participants each expect to share a mutual identity in their interaction and also expect actions that are reciprocal in mutual benefit (fairness). For example, two participants in a church as priest and congregant both expect each to believe in the same religious faith (as members of the same church or synagogue or mosque) and that shared religious practice will enhance each other's service to and benefit the religion.

Next one can call the kind of social interactions that anticipate benefits of both identity and authority as a kind of political interaction. Therein two participants each expect to share a mutual identity in their interaction but also expect actions to be decided by the one participant superior in societal authority and performed by the inferior participant. The participant-superior-in-authority is said to hold political power over the other participant. For example, a political office-holder such as a judge in a court-of-law can sentence another participant in a trial (having been brought into court as an arrested offender) to a sacrifice of life or freedom or property. The judge has legal power over the defendant in a trial.

Finally, one can call the kind of social interactions that anticipate benefits of both utility and authority as a kind of science \& technological interaction. Therein two participants each expect from their interaction a usefulness (utility) and also that utility is based upon an action (technical process) which can effectively create the utility - a methodological authority which guarantees the technical effectiveness of the useful action. For example, as a business person might hire an engineer to design a factory to produce the business person's product. (One example is that of a chemical engineer hired to design chemical processes for producing chemicals.) In this interaction, the engineer's useful action in designing a factory is based upon his methodological authority of engineering knowledge.

This structural-functional systems taxonomy can then be used to construct a sectoral structure-functional model of a modern society as shown in Figure 6.

\section{Stasis Model of Hassan Al-Assad's Syria}

We now use this model to analyze the stasis of Hasan al-Asaad's stable state of Syria, as shown in Figure 7. And what we can see is how the ideas in the political 


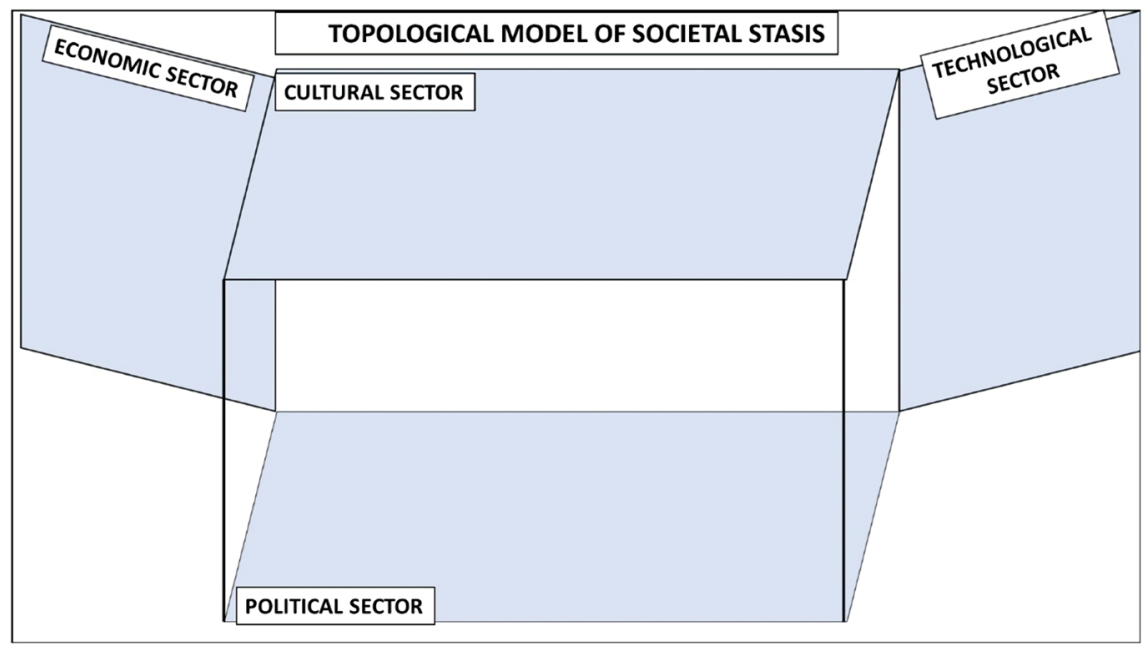

Figure 6. Topological model of societal stasis with four functional sectors.

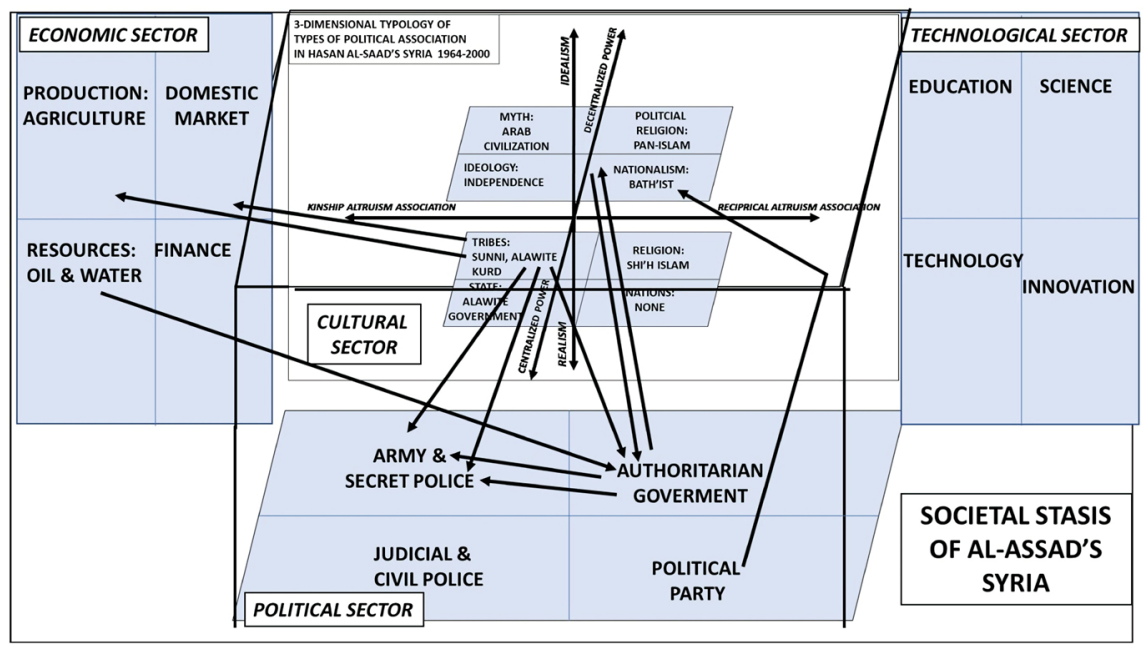

Figure 7. Thematic connections between the theory of political association and institutionalization of government practices in Al-Assad's Syria.

association in al-Assad's Syria connected to (influenced, impacted, justified, guided) the institutionalization of practices in the organization of Syria's Cultural, Political, Economic and Technological Sectors of society.

The black arrows show the connections between the ideas of political association and the institutionalization of societal practices in the different societal sectors. In the structural-functional sectors of Al-Assad's Syria, the model shows how the ideas (themes) in the theory-of-political-association were connected to the institutionalization-of-the-societal/behavioral-patterns-of-participants.

These two models (thematic model and functional model) depict how to connect "ideas" (political-association) with "operations" (practice) of societal institutions. connecting ideas-to-practice in a society.

\section{Cultural Sector}

In the Cultural Sector of the Syrian State under President Hassan al-Assad, tribal and religious associations dominated the politics and government of the 
state.

The Realism of the State as an Alawite dominated government provided the conceputal basis of al-Assad's Authortarian Government. The Realism of Alawite Clans provided the Officers for the Syrian Army and the Staff of the Secret (or Security) Police. The Realism of Religion was the Shi' bonding together of the Alawite participants in al-Assad's Autoritarian Government; all the while, the Idealism of Bahist Arab Nationalism was used to justify the authority of the State. The Realism of the Alawite clans participated in Agriculture and Government; while the Realism of Sunni Muslims participated in trade in the large cities of Syria.

For example, Beverley Milton-Edwards wrote: "Syria was not an ethnic or sectarian homogenous state. In fact, since the creation of a new state of Syria in 1920, a mosaic of minorities have made up its population. The minorities included Alawites, Kurds, Druze, Christians, Turks, Circassian, Armenians, Assyrians, Jews and Maronites... In considering the formation and structure of the modern Ba'thist state and the role of the Aalawites within this, the crucial point is the rise of Alawites in the Syrian armed forces and the Ba'th Party... The Ba'thist agenda had a particuar appeal to the rural poor of areas like Alawite-dominated Latakia, and this openness facilitated their entrance into anad rise within the party... In the late 1960s following the purge first of Sunni officers, then Druze officers, and finally an internal Alawite power strugge in which Hafiz al Assad defeated his co-religionst and fellow officer Sala Jadid. President Hafix al Assad and his successor son Bashar, promoted fellow Alawites in the Army."

\section{Political Sector}

In this stasis model of Hassan al-Assad's rule over Syria, one can see that the political sector, al-Assad's government dominated Syrian society, with control over Syrian citizens by the political police (security apparatus, Mukhabarat) and by the Syrian Army (run by Alawite officers). The Syrian resource of oil provided revenue for Assad to run the government but insufficient to fund the whole Assian economy. The economy was primarily agricultural, within the center of Syrian irrigation along the Euprates river.

\section{Economic Sector}

Syria's economy was primarily agricultural and retail, relying on manfuactured imports of goods and weapons. An oil industry was operated by the state as a source of government revenue. Syria received its weapons from the Soviet Union, in a Bathist alignment with that country.

\section{Technological Sector}

Little was invested in developing science or technology; and education was limited to the first grades, high school in cities, and one undergraduate college.

In summary, this topological model of the structural-functional sectors of Syrian society displays how the Realism/Idealism of concepts of Political Association interacted with the organization and function of operations (structural-functional model) of Syrian society under Hassan al-Assad's Bahist rule of Sy- 
ria.

One can see in this model that Hassan al-Assad's sole dependence upon tribal and religious factors to organize his authoritarian government had left the marjority of Syria's citizens (Sunni Muslims) outside the bounds of government largess and privligees. This resulted in uprisings by the Sunni Muslim Brotherhood and a major slaughter of Alleppo citizens. Thus al-Assad left an inherently unstable state: which he had failed to make a stable nation (under a Roussian contract of equity and service to Sunnis in return for their loyalty). This inherent state-instability was to explode again under Hassan's successor, his son Bashar.

\section{Time Line: Syrian Civil War under Bashar Al-Assad}

Figure 8 summarizes the key change events of Syrian society under Bashar al-Assad's government.

June 2000, Hafez al-Assad died; Bashar al-Assad, his son, was selected as President, in an unopposed election. Raymond Hinnebush wrote: "To prevent a power struggle, the process Hafiz had begun of establishing his son, Bashar, as his successor was ratified.. Bashar al-Assad's project, on his accession to power, was to open the economy to the world market and adapt the country to the age of globalization through measures such as introduction of the internet. Ba'athist ideology was abandoned ... and Bashar al-Assad built up his own reformist faction. His first priorities were to foster modernizing cadres and strengthen state institutions through administrative reform. In principle, the regime sought a 'middle' way, expanding the private sector while reforming rather than privatizing the public sector, and maintaining social protection during economic liberalization, as embodied in the slogan of the 'social market' economy adopted in 2005. However, this middle road, designed to retain the regime's old base while adding new support, failed because the regime had no strategy for actually implementing a 'social market' economy. Moreover, the jettisoning of

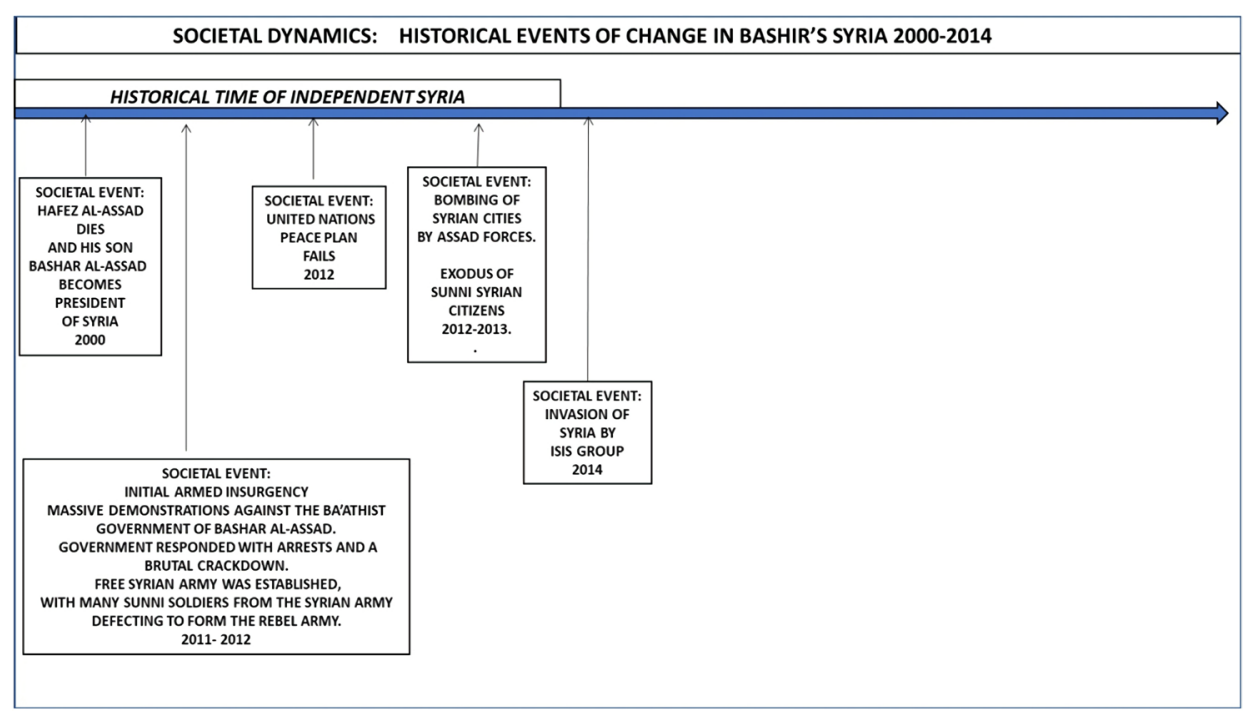

Figure 8. Time-line of Hafez Al-Assad' Syrian government 2000-2014. 
Ba'athist ideology left a vacuum which neo-liberalism and Islamism would compete to fill." (Hinnebusch, 2012)

The economy under Bashar al-Assad did not proper; and an intense drought occurred from 2006 to 2011. There was crop failure, increase in food prices and migration of farming families into cities. In 2010, Syria's GDP was only $\$ 2834$, far lower than neighboring Lebanon. Bashar al-Assad's policies continued to favor Alawites.

\section{1-2012 Initial Armed Insurgency}

Massive demonstrations occurred against the Ba'athist government of Bashar al-Assad; and the government responded with arrests and a brutal crackdown. A rebel Free Syrian Army was established in July 2011, changing the protest into an armed rebellion. Many Sunni soldiers from the Syrian Army defected to form the rebel army.

Yehhia Tashjian wrote: "It would be inaccurate to classify the Syrian uprising as a secular one. Most participants are devout Muslims inspired by Islam. A minority is secular, and another minority is Islamist (some even radical) while the vast majority is religious minded nationalist people from rural areas. In addition, mosques became central to Syria's demonstrations in the first months of the uprising, and Sunni clerics played an important role in it... The Syrian crisis is important part of the Arab Uprising and the regional balance of power... President Assad denied the existence of civil protests in Syria and spoke of the "foreign backed conspiracy" threatening his country. "Many people were misled in the beginning, thinking that what is happening is a state of excitement, a wave of the 'Arab Spring' ... [But it] isn't a revolution or a spring; it is terrorist acts in the full meaning of the word," he proclaimed ... the Syrian president disregarded the popular demands and beliefs of the people and claims that it's a foreign backed conspiracy. Moreover, not only Syria became unstable but the conflict spread to the neighboring countries, the crisis ... polarized the Sunni-Shia tensions in the region. Finally, the conflict took a global form and a new cold war era started from Syria." (Tashiian, 2012)

The Alawites composed $12 \%$ of the Syrian population but made up $90 \%$ of the Army officers. Yehhia Tashjian wrote: "The Syrian army can be characterized as a largely patrimonial force. It has been dominated by sectarian and family ties to the Assad regime, with widespread emphasis on cronyism and favoritism. Instead of being a relatively apolitical institution committed to the national interest, the army has been an instrument of crackdown." (Tashjian, 2012)

The political support for the Assad rule was the Alawite clans and Sunni merchants in Damascus. Yehhia Tashjian wrote: "Alawite political dominance took such forms as the control of security, military and intelligence positions. However, there was a civilian decision-making group in which Sunnis, with a strong Damascus component, have the upper hand. Hence, the al-Assad regime was consolidated through a historic alliance between the predominantly Alawite military officer corps and the Sunni merchant-business class, in particular, its Damascene component." (Tashjian, 2012) 
The lack of Sunni support for the al-Assad rule was outside Damascus. Yehhia Tashjian wrote: ... the protests have been strongest in the southern city of Daraa that sits at the heart of an agricultural plateau, the cities and rural areas of Homs, Idlib, Hama, and the suburbs of Damascus. Due to three decades of state divestment, trade liberalization, neglect of agriculture in the rural areas and government priority to the services sector." (Tashiian, 2012)

The Muslim Brotherhood was responsible for the revolt against Bashar's father but not responsible for the revolt for against Bashar's regime. Naomi Remirez Diaz wrote: "In March 2011, a popular uprising in Syria - following the lead of the revolutions in Tunisia, Egypt, Yemen, Libya and Bahrain - challenged the stability of the apparently unshakable Assad regime that had ruled Syria for the previous four decades. During that time, the absolute power of the security services, the high echelons of the Army and the core of the regime had only been challenged once. That was during the so-called Muslim Brotherhood uprising between 1976 and 1982... However, the beginning of the revolution in Syria in 2011 brought the Brotherhood back to the political scene, where they have played a very important role." (Diaz, 2018)

The year of the revolt had already been troublesome for the regime Naomi Remirez Diaz wrote: "In a particularly difficult year for the Syrian regime, when its Army was forced to withdraw from Lebanon (as a result of the Cedar Revolution against its presence in the country), an amalgam of both the opposition inside and outside the country united under the banner of the Damascus Declaration. They demanded a change in the regime and a transition to democracy, as well as, for the first time, the granting of rights to Kurdish individuals deprived of their citizenship since 1962. They made sure to emphasize the national character of this coalition so as not to give the chance to the regime to accuse them of being part of the international conspiracy initiated by the US invasion of Iraq and followed by the accusations of the Syrian regime's involvement in the Lebanese ex-Prime Minister Rafik Hariri’s assassination in 2004.” (Diaz, 2018)

It was the Arab Spring which encouraged the Syrian Sunni and Kurds to rebel. Naomi Remirez Diaz wrote: "The Egyptian revolution proved to be an important model for the Syrians to follow and some of those who believed something similar could also happen in their country set up a Facebook page calling for a Syrian 'Day of Rage' on February 15, 2011, but to no avail. In spite of this initial reticence, only a few days later, on February 17, 2011, a spontaneous episode in the Hariqa souk in Damascus ended up with dozens of people shouting at a policeman: 'The Syrian people will not be humiliated' (as-shaab as-suri ma biyenzall). It was a popular explosion of "rage" nobody could claim to have orchestrated." (Diaz, 2018)

It was Bashar's militant response to the protests which ignited the revolt. Yehhia Tashjian wrote: "From the first months, protestors had expressed their ideas by singing and raising slogans and pictures. When the crackdown of the protesters continued, the uprising took a violent path. In July 2011, the defected Co- 
lonel Riad al-As'ad declared the formation of the 'Free Syrian Army' (FSA), which would 'protect the peaceful protesters from Assad's army'. Few months later, FSA declared that it will overthrow the regime by the use of force and 'liberate' the country. The rebellion took a violent path and radicalized and foreign Jihadists infiltrated. Syria's geopolitical importance and its relations with Iran and Russia internationalized the domestic crisis." (Tashjian, 2012)

2012 April-May, United Nations and Arab League Peace Plan

A peace plan led by Kofi Annan tried to obtain a ceasefire in the civil war between the al-Assad government and the Free Syrian Army. (April-May 2012) but failed to be implemented. On May 25, 2012, in the town of Taldou (a town northwest of Homs), a group related to the Syrian Army massacred 198 people, including 24 women and 49 children. Following this, the Free Syrian Army launched a series of attacks against the Syrian Government, ending the attempt of the UN and Arab League to continue a ceasefire. During the winter of 2012-13, Syrian rebels advanced in taking territory away from government control. A no-fly zone to be enforced by the U.S. was not implemented.

\section{3-2014, Bombing Civilians in Syria}

The Syrian Army stopped the advances of Sunni rebels in Idib. But the Syrian Army consisting of Alawite soldiers was too small to retake rebel-held towns outside Damascus. The Syrian Air Force began the systematic bombing of Syrian cities, driving Sunni Syrians to flee Syria into Turkey and into Lebanon. Barrel bombs were used by helicopters to level Syrian cities. Iran sponsored Hezbollah soldiers from Lebanon assisted the Syrian Army in capturing some cities near the Lebanon-Syria border.

Matthew Bell wrote: "Syrian military forces are using a new tool in their long-running war against rebels who want to oust President Bashar al-Assad from power. They're called 'barrel bombs' and they were dropped by Syrian helicopters in the northern city of Aleppo on Sunday. The crude-but-deadly devices brought the death toll in the latest campaign to more than 80 people, according to anti-government activists. Most of the victims killed in recent days have been civilians, said the British-based Syrian Observatory for Human Rights... 'Essentially, they're just an old oil-barrel packed with explosives, shrapnel and maybe some kind of incendiary device,' said Aryn Baker, Middle East bureau chief with Time. 'They are literally pushed out of the helicopter and when they land-they detonate on impact-and explode. [They] take down whatever is in their path.' Baker said Syrian forces started using the weapons in 2012. But it has really been the last six weeks or so that has brought a significant uptick in reports of their use. Some in the international community say these devices amount to a war crime." (Bell, 2014)

Figure 9 shows a dropped barrel bomb on the Syrian city of Aleppo in 2014.

Matthew Bell wrote: "Government forces have really been wreaking disaster on Aleppo in the last month, killing men, women, and children alike," said Ole Solvang, senior emergencies researcher at Human Rights Watch. "The Syrian 


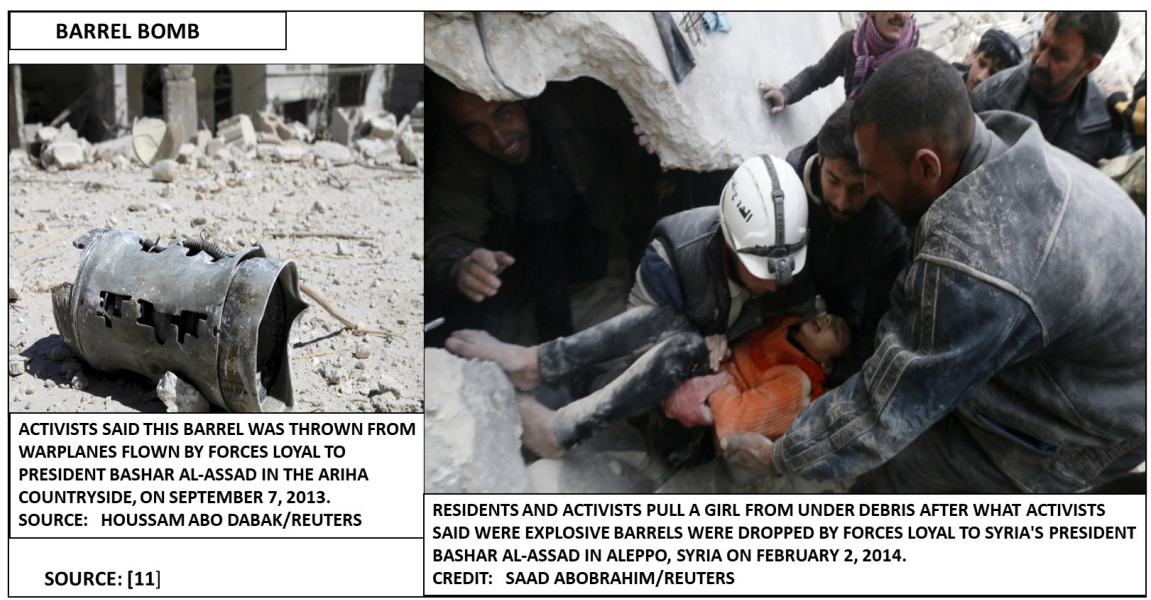

Figure 9. Syrian air force dropped barrel bomb in Aleppo.

Air Force is either criminally incompetent, doesn't care whether it kills scores of civilians-or deliberately targets civilian areas." On occasion, Syrian rebels have managed to bring down government aircraft with shoulder-fired anti-aircraft missiles. That has prompted Syrian helicopters to drop their explosive barrels from altitudes of near 7000 feet, according to Richard Lloyd, who's written a detailed post about Syrian barrel bombs at the Brown Moses Blog. From that height, the weapon becomes an arbitrary killer, especially when dropped on cities with a civilian population. "The main objective of the Syrian barrel bomb program is to provide cheap and lethal damage on urban areas in Syria," Lloyd explained in the post." (Bell, 2014)

Jamie Detter wrote: "For those looking at Syria's four-year-long conflict from the outside, the slaughter has appeared to have little or no pattern, a barbaric struggle in which all are equally guilty. But a new survey of blood-curdling sectarian massacres perpetrated in Syria since the start of the civil war provides a very clear picture of the ultimate villain behind the carnage. According to the survey by the Syrian Network for Human Rights, there have been 56 major massacres displaying obvious sectarian or ethnic cleansing traits. Of these 49 were carried out by Syrian government forces or local and foreign militia allies of President Bashar al-Assad, making a mockery of the Syrian leader's frequent claim to foreign broadcasters that his soldiers would never harm their own people deliberately as a matter of policy (Detter, 2015).

The systematic bombing of Syrian cities outside of Damascus by the Syrian Air Force continued from 2013 through 2014, resulting in a mass exodus of Syrian citizens from these cities.

\section{Connecting Theory of Political Association with Structural-Functional Model}

We can again use the two models of the thematic ideas of Political Association and of Structural-Functionalism to explain how decisions made by Bashar al-Assad's government resulted in an unstable state and not a nation. The func- 
tional instability of the government continued under Bashar's reliance on the idea of the Shite tribal group of the Alawite clans to run a Sunni-majority Syria. The Sunni majority rebelled; and Bashar's Alawite government responded by bombing Syrian cities. The bombing resulted in a Sunni exodus from Syrian cities, leaving them vulnerable to occupation by the ISIS/ISIL militia. Figure 10 shows the thematic connections to functional activities in Bashar's Syria.

\section{Cultural Sector}

As under President Hassan al-Assad, the Cultural Sector of the Syrian State under President Bashar al-Assad had the tribal and religious associations dominate the politics and government of the Syrian state. Bashar continued unchanged the Realism of the State as an Alawite-dominated government, which provided the conceputal basis of continuing an al-Assad Authortarian Government. The Realism of Alawite Clans continued to provide the Officers for the Syrian Army and the Staff of the Secret (or Security) Police. The Realism of Religion was the Shi' bound together the Alawite participants in al-Assad's Autoritarian Government; but, all the while, the Idealism of Bathist Arab Nationalism was used to justify the authority of the State. The Realism of the Alawite clans participated in Agriculture and Government; while the Realism of Sunni Muslims participated in trade in the large cities of Syria. Feeling themselves politically and economically oppressed, the Sunni Muslims in the Syrian cities (other than Damascus) rebelled.

Thematic ideas in culture provided the justification of the Realism of goverance by the Alawite minority and the justification of rebellion in the Realism of the Sunni marjority.

\section{Political Sector}

Bashar continued his father's rule over Syria, and the political sector run by an Alawite dominated Syrian society, with control over Syrian citizens by the political police (security apparatus, Mukhabarat) and by the Syrian Army (run by Alawite

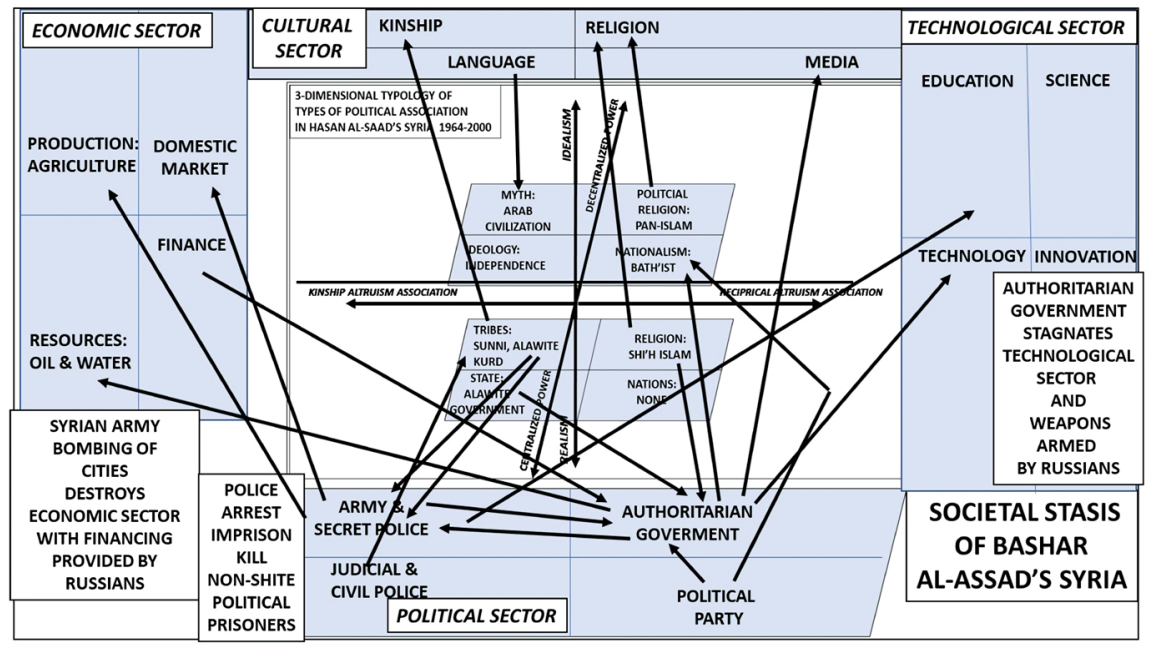

Figure 10. Connections between ideas of political association and operations of Bahar Al-Assad's Syria. 
officers). The Syrian resource of oil provided revenue for both Assads, father and son, to run the government but was insufficient to fund the whole economy.

\section{Economic Sector}

Syria's economy was primarily agricultural and retail, relying on manfuactured imports for goods and weapons. An oil industry was operated by the state as a source of government revenue. Syria received its weapons from the Soviet Union, in a Bathist alignment with that country. Under Bashar, the economy continued primarily agricultural, with in the center of Syrian irrigation along the Euprates river. And severe drought in agriculture contributed to Sunni unrest and rebellion.

\section{Technological Sector}

Little was invested in developing science or technology; and education was limited to the first grades, high school in cities, and one undergraduate college. However in 2004, the introduction of the Internet focused one government agency on new technology. The Syrian Government announced: "The Ministry of Communications has been renamed the Ministry of Communications and Technology. It takes charge of developing government communications and information policies and setting strategies and implementation programs in this field with the aim of upgrading and ensuring the security of their systems, organizing the two sectors, and proposing necessary legislation in concert with other government programs. The Ministry also handles modern technology transfer. Its work contributes to social and economic development and to preparing Syrian society to communicate with the international information community. It also works on enhancing the introduction of IT into government bodies, providing applied services to these bodies, preparing feasibility studies, launching guidance projects to help generate, collect, classify and publish information in cooperation with the concerned bodies." (Syrian Government, 2004)

In a summary of the societal model, again under Bashar's rule, the topological model of the structural-functional sectors of Syrian society displays how the Realism/Idealism of concepts of Political Association interacted with the organization and function of operations (structural-functional model) of Syrian society under the continuing al-Assad's Bahist rule of Syria.

One can see in this model that both Hassan and Bashar's al-Assad's dependence upon tribal and religious factors to organize their authoritarian governments had left the majority of Syria's citizens (Sunni Muslims) outside the bounds of government largess and privileges. This resulted in uprisings by the Sunni Muslim Brotherhood and a major slaughter of Alleppo citizens under Hassan and then a destruction of Syrian cities under Bashar. Thus al-Assad regimes ruled inherently unstable states. Both father and son Alawite rulers failed to make a stable nation (under a Rousseauian contract of equity and service to Sunnis in return for their loyalty).

\section{Discussion}

The Al-Assad regimes were constructed upon an inclusion of Syrian Alawite 
clans in the Ba'athist government and exclusion of Syrian Sunni Muslims. Thus, the Syrian state was not built up as a nation, with a Roussian contract of equity to all citizens-only equity to Alawites but not to Sunni's. This created an unstable state, with periodic Sunni rebellions. Hafez al-Assad put down one rebellion by slaughtering thousands of Sunni Syrians in the city of Aleppo. Bashar al-Assad put down a second rebellion by slaughtering over 240,000 Syrian civilians and displacing or exiling over 7.6 million Syrian civilians. This resulted in a Syrian diaspora out of Syria, as shown in Figure 11.

In addition to bombing cities, Bashar's police imprisoned, tortured, and killed over 100,000 Syrian citizens: in 2019, Anne Barnard wrote: "As Syria's president, Bashar al-Assad, closes in on victory over an eight-year revolt, a secret, industrial-scale system of arbitrary arrests and torture prisons has been pivotal to his success. While the Syrian military, backed by Russia and Iran, fought armed rebels for territory, the government waged a ruthless war on civilians, throwing hundreds of thousands into filthy dungeons where thousands were tortured and killed. Nearly 128,000 have never emerged, and are presumed to be either dead or still in custody, according to the Syrian Network for Human Rights, an independent monitoring group that keeps the most rigorous tally. Nearly 14,000 were 'killed under torture'. Many prisoners die from conditions so dire that a United Nations investigation labeled the process 'extermination'. Now, even as the war winds down, the world's attention fades and countries start to normalize relations with Syria, the pace of new arrests, torture and execution is increasing. The numbers peaked in the conflict's bloodiest early years, but last year the Syrian Network recorded 5607 new arrests that it classifies as arbitrary-more than 100 per week and nearly 25 percent more than the year before." (Barnard, 2019)

Earlier, the prison had been established by Bashar's father. Anne Barnard wrote: "The Syrian detention system is a supersized version of the one built by Mr. al-Assad's father, President Hafez al-Assad. In 1982, he crushed an armed Muslim Brotherhood uprising in Hama, leveling much of the city and arresting tens of thousands of people: Islamists, leftist dissidents and random Syrians. Over two decades, around 17,000 detainees disappeared into a system with a torture repertoire that borrowed from French colonialists, regional dictators and even Nazis. Its security advisers included Adolf Eichmann's fugitive aide Alois Brunner. When Bashar al-Assad succeeded his father in 2000, he kept the detention system in place." (Barnard, 2019) (Figure 12)

The Alawite Syrian Army was too few in numbers to reoccupy the Sunni rebel cities outside Damascus, such as: Homs, Hama, Idib, Aleppo, Ar Raqqah, Deir ez-Zor. The bombing depopulated these cities - emptying them, making them susceptible to the next rebel group which marched into to conquer them. And this is what Isis did in 2014. Then Bashar al-Assad came close to losing all of Syria, until the Russians saved him. But this "save" is analyzed in the next paper of this 4-paper series-on the rise and fall and continuation of a state called "Syria". 


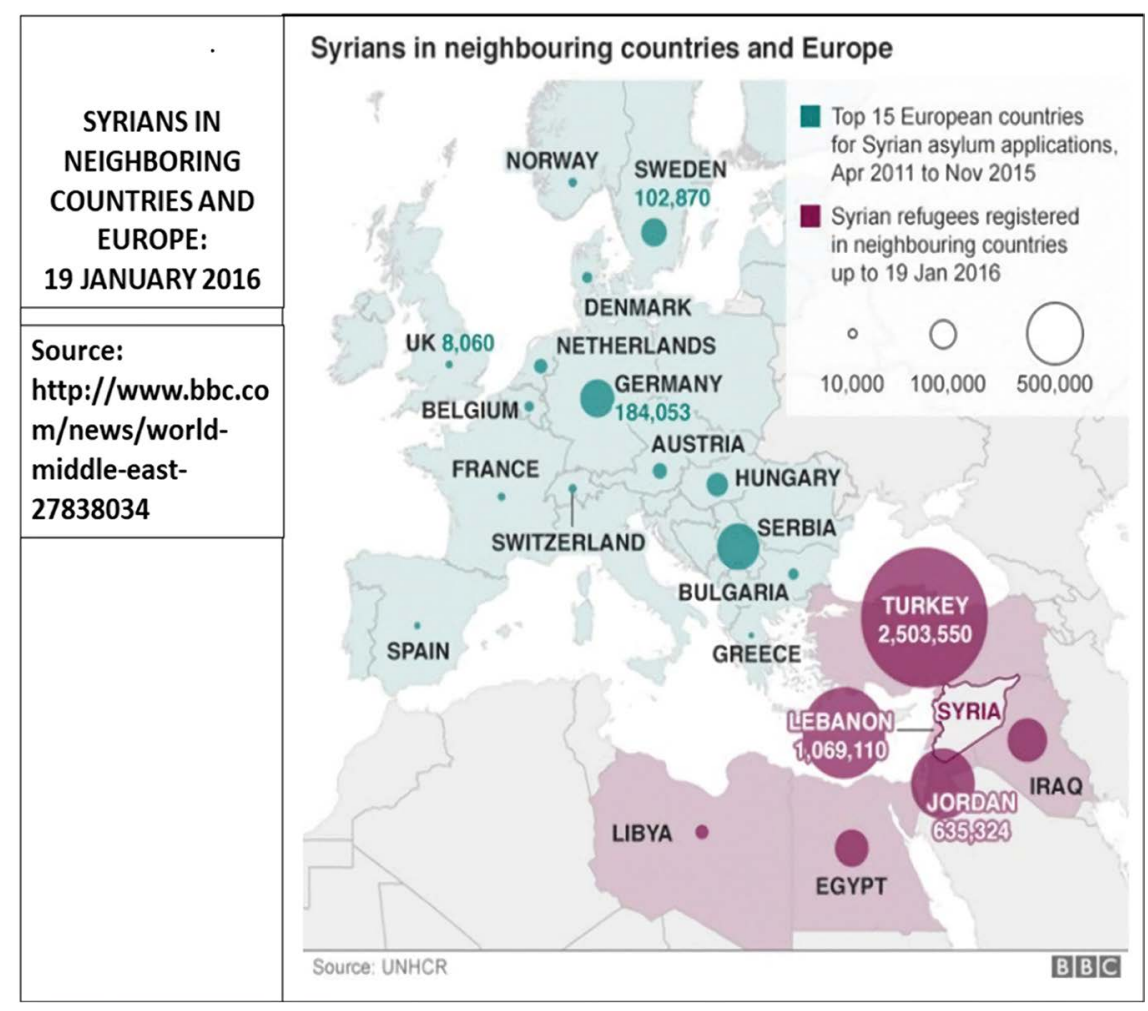

Figure 11. In 2016, the dispersion of Syrian Sunni Muslim citizens as refugees from the bombing of Syria by the Syrian air force. (Source: Atlas-Syria: Federal Ministry of the interior, Republic of Austria, 2015, http://www.ecoi.net/atlas syria.pdf, p. 19)

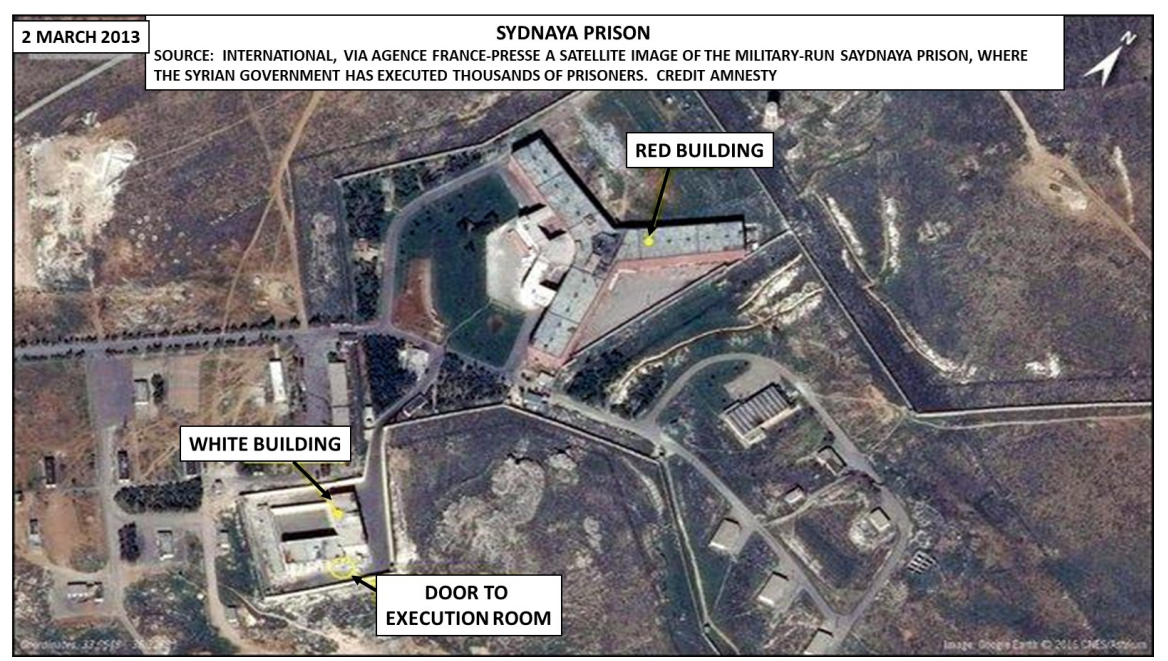

Figure 12. Sydnaya prison in Syria.

\section{Conclusion}

After independence, the history of Syria empirically illustrates and verifies the theory of political association-in that the theoretical distinctions between "state" and "nation" are fundamental concepts in the politics of a society (Betz, 2019). The organization of the al-Assad governments was based upon a tribal and religious divisions among Syrian citizens-Shi'a Muslim Alawite clans 
against Sunni Muslim citizens.

So far (covering the history of the Middle East at the fall of the Ottoman Empire, the colonial occupation of Syria and the independence of Syria), we have in two papers used Syrian history to provide empirical societal evidence that verifies the validity of a theory of political association (expressed in a 3-dimensional taxonomy). This theoretical taxonomy is constructed by three pairs of political dichotomies: 1) Kinship-Altruism-Association \& Reciprocal-Trust-Altruism Association, 2) Decentralized-Power \& Centralized-Power, 3) Idealism \& Realism. This formal theory has been useful in explaining the societal dynamics of the territory of Syria. In particular, it explains that the Realism (Power Analytics) existed in the Tribal/Religious domination of an Alawite group over other groups of Sunni Muslims, despite the Idealism (Ideology) of the Ba'athist governments for a united Syria.

We also showed how to connect models of ideas (themes) to models of societal organization (function-structural) in depicting how the Syrian government functions were organized around Alawite ideas of Shite versus Sunni. Models of ideas, such as the theoretical ideas of political association, impact societal structures, through institutionalization of practices in the functional sectors of society.

Connections occur between the ideas of political association and the practices in the functional sectors of a society (cultural and political and "economic" sectors of the society). These connections can be modeled by connecting the theoretical model of political association to a Weberian four-sectoral societal model of a societyl state.

We have seen that the conceptual distinction between a "state" and "nation" is not only theoretically accurate in explaining the dynamics of independent Syria but also practically important in explaining how the Alawites of Syria constructed the independent Syrian "state" - but an unstable "state". Alawite policy of excluding Sunni participation in government and in economic policy fostered Sunni antagonisms and periodic Sunni rebellions. Rather than choosing a policy of reform to include Sunni participation in government, the al-Assad regimes chose to imprison, kill, and bomb Sunni citizens-until Syria cities outside of Damascus were de-populated. Then another tribal-religious group, the Isis, rolled into Syria in 2015 and threatened the collapse of the Alawite government, even in Damascus. In a next third paper, we continue the analysis of the failure of Syrian in terms of political-association theory and the consequences of state-failure on citizens of the Syrian territory.

\section{Conflicts of Interest}

The author declares no conflicts of interest regarding the publication of this paper.

\section{References}

Barnard, A. (2019). Inside Syria's Secret Torture Prisons: How Assad Crushed Dissent. 
New York Times, May 11.

https://www.nytimes.com/2019/05/11/world/middleeast/syria-torture-prisons.html?act ion $=$ click\&module $=$ Top $\% 20$ Stories\&pgtype $=$ Homepage

Bell, M. (2014). What Are "Barrel Bombs" and Why Is the Syrian Military Using Them? Public Radio International PRI's the World February 04.

https://www.pri.org/stories/2014-02-04/what-are-barrel-bombs-and-why-syrian-milita ry-using-them

Betz, F. (2011). Societal Dynamics. New York: Springer.

Betz, F. (2019). Political Theory of Societal Association: Case of the Failed State of Syria, Part 1. Open Journal of Social Sciences, 7, 271-296. https://www.scirp.org/journal/jss

Büchs, A. (2009). The Resilience of Authoritarian Rule in Syria under Hafez and Bashar Al-Asad. GIGA Research Programme, Institute of Middle East Studies.

https://www.giga-hamburg.de/en/system/files/publications/wp97 buechs.pdf https://doi.org/10.2139/ssrn.1369189

Detter, J. (2015). A Damning Indictment of Syrian President Assad's Systematic Massacres. The Daily Beast, June 19, 2015.

https://www.thedailybeast.com/a-damning-indictment-of-syrian-president-assads-syst ematic-massacres

Diaz, N. R. (2018). The Muslim Brotherhood in Syria: The Democratic Option of Islamism (Routledge/St. Andrews Syrian Studies Series) (Kindle Edition).

Hinnebusch, R. (2012). Syria: From “Authoritarian Upgrading” to Revolution? International Affairs, 88, 95-113. https://doi.org/10.1111/j.1468-2346.2012.01059.x

Kaplan, R. D. (1993). Syria Identity Crisis. The Atlantic, 271, 22-26. https://www.theatlantic.com/magazine/archive/F1993/02/syria-identity-crisis/303860 https://doi.org/10.3817/0393099287

Milton-Edwards, B. (2018). Contemporary Politics in the Middle East (4th ed.). Cambridge: Polity Press.

Parsons, T. (1951). The Social System. New York: Free Press.

Syrian Government (2004). Syrian Ministry of Communications.

http://www.moct.gov.sy/standards.php?b3A9bW9kbG9hZCZuYW11PVN1YmplY3RzI mZpbGU9aW5kZXgmcmVxPXZpZXdwYWdlJnBhZ2VpZD01MzdlbmRlbmRlbmRlb $\underline{\mathrm{mRlbmQ}}$

Tashjian, Y. (2012). The Syrian Crisis; from Local Uprising to Regional-International Struggle. Strategic Outlook.

https://d1wqtxts1xzle7.cloudfront.net/31316091/The Syrian crisis from local uprisi ng to regional-international struggle.pdf? $1369820621=$ \&response-content-dispositio $\underline{\mathrm{n}=\text { inline } \% 3 \mathrm{~B}+\text { filename\%3DThe Syrian crisis from local uprising to.pdf\&Expires }=1}$ 592583169\&Signa

Weber, M. (1947). From Max Weber: Essays in Sociology. New York: Oxford University Press. 